\title{
DRAFT
}

\section{Critical Social Psychology and Interdisciplinary Studies of Personal Life: Greater than the sum of its parts}

\author{
Maree Martinussen
}

\begin{abstract}
Singleness, parenting, sexual practices, sibling rivalries, through to meal times, investigating how intimacies and personal lives are organised have always been a mainstay in critical social psychology. However, in the interdisciplinary field of studies of personal life, sociologists often take the lead. In this article, I discuss three illustrative examples - family practices, queered studies of personal life, and emerging emotional regimes in 'late modernity', and ask how critical social psychology, with its history of investigating the social processes of subjectivity-making, could be deployed to resolve debates that have emerged within a sociology of personal life. I suggest that clarifying critical social psychology's position in relation to broader studies of personal and intimate life would showcase the distinctiveness of critical social psychological contributions in understanding relational selves, whilst simultaneously fostering interdisciplinary working.
\end{abstract}

Keywords: Personal life, practices of intimacy, critical social psychology, interdisciplinary, queering, emotional subjectivities

\section{Introduction}

An important advancement of second wave feminism was to establish studies of care and intimacy on the social science agenda, demonstrating the centrality of 'private' matters to the functioning of every aspect of social life. Contributions to studies of families, intimacies, care and personal life can be found throughout geography (Nash, 2005; Wright, 2010), social policy (Henderson \& Forbat, 2002; Daly, 2011), mainstream social psychology (Fagundes \& Diamond, 2013; Meyers \& Berscheid, 1997), cultural studies (Berlant, 2013; Lee, 2007), queer studies (Park, 2013; Stacey, 1996) and law (Bornstein, 2012; Rosenbury \& Rothman, 2010). Likewise, largely due to feminist influences, topics of personal life have always been central to critical social psychology, evidenced today in research investigating relationships (Meenagh, 2017), communities (Johnson, 2012), support networks (Gibson, Wilson, Grice, \& Seymour, 2017), or the experiences of love (Watts, 2017). Even in critical social psychological research whose focus may not be primarily oriented to matters of personal life - perhaps gendered constructions of cigarette smoking (Triandafilidis, Ussher, Perz, \& Huppatz, 2017), interactional organisation of threats (Hepburn \& Potter, 2011), or Muslim women negotiating further education (Hussain, Johnson, \& Alam, 2017) - participants' identities as people in meaningful personal relationships are inherently at stake. Critical social psychologists have excelled in outlining how our sense of ourselves as daughters, sons, parents, siblings, friends, sexual beings or carers represent some of the identities in which we are most invested. While there are touchpoints with many other disciplines, sociology's contributions to studies of personal life are perhaps the closest to the interests of critical social psychology. Sociology has a long history of housing various sub-disciplines from which to explore issues of personal life, often linked to social justice issues. Further, comprehensive, theoretically and empirically oriented research agenda and methodologies have been developed and the need for greater interdisciplinary working has been elaborated 


\section{DRAFT}

upon (Gabb, 2010; Roseneil \& Ketokivi, 2015). In this article I ask what a sociology of personal life and a critical social psychology of intimate relating might offer each other, acknowledging distinct histories, specialisms and trajectories.

The development of a more interdisciplinary-capable critical social psychology of personal life is timely. It is important to ask how neoliberalism, understood across the social sciences as the most powerful metanarrative of the moment (Peters, 2001), intersects with the organisation of personal life. A focus on neoliberalism, along with associated motifs of individualisation, responsibilisation, globalisation and (im)mobilities, provides the background for sociological claims that we have entered an era in which intimate life and associated identities have an unprecedented gravity and salience in the 'western world' (Bauman \& May, 2001; Beck \& Beck-Gernsheim, 2002; Giddens, 1991; Rose, 1999). If we take these claims seriously, we cannot hope to provide answers about who we are in the $21^{\text {st }}$ century without greater understanding of how close relationships are carried out and organised. Similarly, there is a need for further interrogation of changing formations of subjectivity and emerging emotional regimes relating to intimacy in these neoliberal times.

The remainder of this article hones in on three distinct areas of sociological studies of personal life, and puts them in dialogue with forms of critical social psychology that include subjectivity-making and the process of becoming part of their methodological base. First, I examine David Morgan's concept of family practices; second, the politicisation of nonconventional family formations and the queering the personal life agenda; and third, new forms of intimacy and emotional subjectivities in 'late modernity'. I acknowledge that including such wide-ranging discussions compromises depth of engagement. However, my aim here is to give something of a flavour of the multitude of touchpoints between existing bodies of knowledge and identifying where cross-fertilisation could take place. The resonances and divergences between sociological and critical social psychology traditions will be explored, with the aim of finding complementary expertise, and points at which both disciplines might mutually buttress existing weaknesses and plug knowledge gaps.

\section{Family practices: a transdisciplinary home for studies of personal life?}

David Morgan's 'family practices' concept has been a hugely productive line of sociological enquiry (Morgan, 1996, 2011). Here, I provide an outline, highlighting the potential of the family practices approach as a useful tool-kit in and of itself, but also as a point of connection that could bring together critical social psychologists and sociologists working on topics of personal. I go on to discuss how critical social psychology theorising on managing plural identities can shore up shortcomings in the concept.

A key premise of the family practices approach is that it is intended to "show how "family" is implicated in a whole range of other social institutions and sets of practices' (Morgan, 2011, p.2). Rather than beginning from family per se, one typically starts asking questions about, for example, social class, employment, or religion. From there, the analyst enquires about the family dimensions which might be involved. One benefit of this approach, is that we are pushed towards thinking in terms of plurality, contradictions, multi-modality and relationships between various domains. Attention is drawn to the possibilities of people's assembling of meanings, the blending, juggling, or contrasting of everyday expertise and knowledges from different areas of life. 


\section{DRAFT}

Morgan uses an analogy of a painter blending colours to describe how fields of practice interact. If primary colours are useful to a painter, not just in themselves, but to make new colours, family can be considered a primary colour to blend with others, such as class, gender, or education. When mixed, this site of activity, 'family + gender' for example, is distinct from its constituent parts; parenting, for example, becomes mothering or fathering, which carry the weight of a vast range of meanings and evaluations. Time, space, embodiment or ethics may also stand for such 'primary colours' that become co-constitutive with elements of personal life (Morgan, 2011). Using the parenting example, how might practices be affected by identity as 'step-parent'? Or LGBTIQ+ identity? How might divorced parents' practices taking place in two homes, differ from other parents? Nested within these, perhaps we might consider other topics, 'secondary colours', that could be blended in, for example, eating, nudity, democracy, exercise, social media consumption, dating, fashion and so forth. If interdisciplinary studies of personal life were organised in this way, reflecting fields of practice, critical social psychologists could then 'zoom out', and analyse cultural shifts from a high-level view, but not lose sight of situated psychological accounts in more specific domains.

The family practices approach resonates with critical social psychology through its core premise of working between the social and the psychological, and in treating people as both subject and object. One of Morgan's key points was to emphasise that the family is a process, something we do, and he impresses that family and personal life have an intrinsically everyday character (Morgan, 1996). Evaluations of self as a family member are pervasive in mundane social life, including in situations when family seems very distant or absent, and in situations where these assumptions are unwelcome, oppressive or irrelevant. In studying the routine, taken for granted, practical knowledges articulated in everyday accounts which characterise practice theory approaches more generally (Molloy, 2008), the field of sociology of personal life is effectively pushed into closer alignment with what might be considered process-oriented critical social psychology approaches (e.g. Brown \& Stenner, 2009; Taylor, 2015; Wetherell, 2006). Underpinning such approaches are a commitment to notions such as becoming and emergence, where social formations and identity-making follow patterns, but are inherently contingent, because reflexive, inter-subjective meaning-making is perpetual. Other shared goals between these two traditions is the resistance to binaries of micro/macro, discourse/practice, and structure/agency, and the positioning of people as agents who strategically negotiate resources that are both material and ideological in nature (Morgan, 1989).

Before going further, it seems sensible to clarify what family practices are, and what makes them family practices, as opposed to other social practices. Although family practices are 'inescapably relational' (Morgan, 2011, p.24), unsurprisingly, they simply concern those designated as family by social actors. What distinguishes between different classes of family practices is the particularity of a relationship at a point in time, whether it be a "parent's terminal illness... a daughter's achievements at university [or] the break-up of a brother's marriage" (Morgan, 2011, p.173). That is, the specifics of the engagements with whatever aspect of their intimate life people are engaged with matters, because practices are contingent and contextual. For example, when adapting a family practice approach in a recent study about friendships between women, my aim was to map out some of the practical, routinised and taken-for-granted ways of living out friendship (Martinussen, 2018). With Margaret Wetherell (Martinussen \& Wetherell, 2018b), I show participants' ideals of intimacy are 


\section{DRAFT}

inflected with discourses of therapy, but providing detail of the 'how' meant that a local, Antipodean variety of these discourses was detectable.

So far I have focused on the points of convergence with critical social psychology. Next, I want to highlight some points of divergence, and to suggest that emphases more usual in critical social psychology would add texture to the study of family practices. Morgan is interested in biographical influences, in relationality and the dynamic cultures of families. Together with Clare Holdsworth, Morgan (Holdsworth \& Morgan, 2005) draws on Lefebvre to suggest the complexities of family performances are constituted through the realms of the practical (material), the symbolic (discourse) and the imaginary (individual constructions). Nonetheless, as befits a sociology, most space is given to bounded social identities understood in a relatively categorical way. The relational self, sometimes conceived as an unbounded (Gergen, 2006), distributed (Wetherell \& Maybin, 1996) or dialogically (Billig, 1996) formed self in critical social psychology, is muted in the work of Morgan and his colleagues. Similarly, there is much less attention to the development of a meaningful sense of self accruing over time. How do people use socio-cultural resources available to them, personalising them, so that they come to stand for highly invested aspects of self?

Similarly, although Morgan highlights that "[a]ction is [always] conducted in relation to others", the idea that action is conducted in relation to imagined others is missing. Or, at least, concepts such as positioning, or identity theory linked to everyday ideologies are not utilised (Billig, Condor, Edwards, Gane, Middleton, \& Radley 1988; Harre \& Moghaddam, 2003; Wetherell, 1998, 2003). Further, although Morgan provides rich examples of interactions in different dimensions of social life, and does at times describe them as potentially creating contradictions (e.g. Morgan, 2011, p.112), critical social psychology's emphasis on plurality and the messiness of lived experience is also largely missing from family practices theory. Contradiction (Billig et al., 1988) or moments of interactional or cultural trouble (Wetherell, 2005), can be used as analytic devices, helping us become more attuned to what social actions are being performed, and what dilemmas people are working through. As such, there are opportunities for critical social psychologists to demonstrate how contradictions at the psychological level fundamentally propel social life (Billig, 2009), and to carry out personal life research that attempts to focus on the identity work involved in achieving a sense of unified self as contradictory discourses are mobilised (Edley, 2001). There is a resemblance between this focus on contradiction and some sociological work which has set out to ask how 'new' and 'traditional' practices are blended within couple relationships using the concept of bricolage (Carter \& Duncan, 2018; Duncan, 2011; Morris, 2015). The conclusion that people hold, for example, 'shifting positions, moving between heteronormative, romantic couple-centred ideals, "traditional" versus egalitarian gender roles and experimentation... simultaneously' (Morris, 2015, para. 7.2) is useful. But from here, using critical discursive psychology, we might be able to put more attention on the specifics of the figuring, composing, entangling or recruiting processes in which psychologies become implicated (Wetherell, 2012, p.15). These suggestions do not compete with a family practice approach, but extend it with a different emphasis.

Addressing these theoretical shifts may have methodological implications, which represents another area ripe for collaboration. The goal of developing methodological innovation in high quality qualitative research found in critical social psychology (Braun, Clarke, \& Gray, 2017) is shared with many sociologists working in the personal life field. As Jacqui Gabb's (2010) comprehensive coverage of methodologies used in sociological studies of family life demonstrates, the field is innovative, and attentive to the challenges of researching sensitive 


\section{DRAFT}

field sites. Recent contributions have focused on the mediated intimacies of our 'polymedia environments' (Chambers, 2013), on mixed methods approaches designed to capture nonverbal expressions of 'ordinary emotions' (Brownlie, 2014) and uses of visual, graphic, photographic or activity-based elicitation devices (see Gabb 2010, pp. 43-46). An area where synergies have been capitalised upon is the use of psychoanalytic inspired psychosocial frameworks in sociology of personal life research (Gabb, 2010; Roseneil, 2006; Roseneil \& Ketokivi, 2015). As yet however, there has been limited development of psychosocial research based on everyday practice approaches, such as the family practice approach. Further, the implications of using interview data, which remains the most utilised method in sociology of personal life, are often omitted in sociological research. Although Morgan puts some emphasis on auto/biographical research, in his own words, ' $\mathrm{t}$ ] he relationship between what is said in an interview situation and what is actually done (the core of a practices approach) remains a complex issue within qualitative family studies' (Morgan, 2011, p.169). Critical social psychology's long history of generative debate on language, lived experience and identity could provide methodological and theoretical clarity for sociologists.

\section{Family practices to practices of intimate relating - queering studies of personal life}

One of the very few sustained critiques of the family practices concept is that the specific focus on family, and not personal life more broadly, is restrictive. Social ties in the contemporary era are often characterised by increased flexibility, inventiveness and transience (Chambers, 2012). A focus on 'family' alone does not seem adequate for capturing the fluidity of our emerging relational-scape, evident in the rise in single-person households (Lahad, 2017), blended families (Allan, Crow, \& Hawker, 2011; McCarthy, Edward, \& Gillies, 2003), living apart together relationships (Levin, 2004; Roseneil, 2006a), polyamory relationships (Barker, 2005; Haritaworn, Lin, \& Klesse, 2006) or inclusion of friends as family (Budgeon \& Roseneil, 2002; Weeks, Heaphy, \& Donovan, 2001; Weston, 1991). The impetus behind calls for more inclusive terminology for personal relationships also comes from sociologists who point out that the diversification of new forms of belonging has been accompanied by moral panic about social decline, within and outside the academy (Chambers, 2001). Others have emphasised the need for caution in our assessments of how much things have changed, arguing that empirical investigation invariably tells a complicated story where old and new forms of togetherness can blend in ways that reproduce existing inequalities. (Gross, 2005; Jamieson, 1999). In light of these debates, small-scale intensive critical social psychological research, could enter into greater dialogue with sociologists who are also detailing the subtleties, complexities and ambiguities of contemporary intimacies. In particular, critical social psychologists' expertise could be used to show how the contradiction involved in doing intimate-self identities gets lived out, including how people juggle with 'older'/'traditional and 'new'/'non-conventional' late-modern intimacies. How are discourses of empowerment being used by women to construct their sexual selves (Meenagh, 2017)? How do practices of casual sex affect the ways individuals can construct themselves as adequately skilled in 'emotional intimacy' (Farvid \& Braun, 2017)? How are celebrations of 'ladette' culture changing what is considered intimate friendship between women (Martinussen, Wetherell, \& Braun, 2018)?

Secondly, and the main topic I want to tackle here, thinking beyond family practices is not just useful to capture heterogeneity, but is necessary to avoid reinstating a heteronormative view of family and coupledom. Sasha Roseneil and Shelley Budgeon have been instrumental 


\section{DRAFT}

in a movement to queer studies of personal life; principally, this has entailed challenging the field to cast a different gaze on the practices of care and intimacy that fall outside the domain of heterosexual couples and family (Budgeon, 2006, Roseneil, 2000, 2006a; Roseneil \& Budgeon, 2004). Other sociologists have found that using terms such as 'personal life' (Smart, 2007), 'intimacy' (Jamieson, 1998) and 'personal communities' (Pahl \& Spencer, 2004) have provided more flexibility in studying a variety of intimacies than is possible than using 'family'.

How can critical social psychologists help to build a queered studies of personal life? Interdisciplinarity is a key part of the answer. For example, in her calls for a queered psychology, Katharine Johnson (2015) suggests that hybrid theorising and transdisciplinarity are central. João Manuel de Oliveira, Carlos Gonçalves da Costa and Nuno Santos Carneiro (2014, p.42) similarly argue that establishing a queer feminist critical psychology will require coming together at 'an intersection of knowledges... from other disciplines and sources'. In particular, there is opportunity to bring theorising from cultural studies, sociology and psychology that is more explicit about its queer focus, together with existing process-oriented critical social psychology of personal life. Existing research has, for example, problematized the normalising imperatives of marriage, co-habitation and coupledom (Braun, 2003; Burns, 2003; Sandfield \& Percy, 2003; Jeffreys, 2004), and relationship categories and sexualities linked to 'life-stages' (Abeyasekera, 2017; Reynolds \& Taylor, 2005; Sandfield, 2006; Ussher, Perz, \& Parton, 2015). These are not found under the rubric of queer research, but they are nonetheless queering. One area that has queering potential, but receives little attention in critical social psychology is studies of friendships and chosen families (for exceptions see Griffin, 2000; Martinussen, 2018; Martinussen \& Wetherell, 2018b, 2018a; Martinussen et al., 2018; Zukas, 1993), which has long been explored in sociology (Budgeon, 2006; Nardi, 1992; Roseneil, 2004; Stacey, 1996).

By bringing queer and process-oriented intimacy research into dialogue, we would then be broadening out the focus on sexual citizenship often found in queer research, to investigating the heteronormative assumptions bound up in everyday ideologies of intimate citizenship (Plummer, 2001). This could prove invaluable in becoming a vantage point, enabling us to see opportunities for queering our imaginaries. Critically, it would also signal that varieties of 'personal life identities' should be included as an important aspect of intersectional analysis (Stokoe, 2003; Addie \& Brownlow, 2014; Lahad, 2017). As mentioned previously, it is in these identities we are likely to hold the deepest of investments. Yet, at present, the significant capacity that relationship statuses have for ordering life (e.g. single, mother/father, married, friend, or non-parent) is not recognised alongside sexuality, class, education, race or health and so forth, in critical social psychology.

\section{Emotional subjectivities in changed cultures of care and intimacy in late modernity}

The debates surrounding pluralising intimate practices go hand in hand with questions of how intimacies have changed as a result of 'liquid'/'late'/'post-modernity'. These are often underpinned by critical studies of neoliberalism, whose key characteristics are "heightened levels of discontinuity and fluidity in social and personal life, increased individual autonomy and the weakening of social bonds" (Binkley, 2018, para. 12). There has not been the same emphasis on the relationship between neoliberalism and broader cultures of intimacies in critical social psychology that has captured sociologists from the 1990s onwards. For example, as has been noted elsewhere, investigations of contemporary constructions of 


\section{DRAFT}

sexual/romantic love tend to come out of sociology rather than critical social psychology (Burns, 2000; Watts, 2017). We might ask then, how can critical social psychology help investigate questions about cultures of individualisation and the psy complex, which encourage us to understand ourselves as unique, autonomous and authentic? And, how do these mooted changes in subjectivity affect our personal relationships? Has the salience of romantic relationships increased to the extent that it is akin to a new religion (Beck \& BeckGernsheim, 1995)? Simultaneously, do we experience an aversion to the permanency of these romantic relationships (Bauman, 2003)? Is this contradictory push and pull experienced in our friendships (Bauman, 1995)? Critical social psychologists in their detailed studies can take a lead from sociologists by considering the significance and scale of cultural shifts in intimacy. Sociologists in turn might want to borrow from the tool-box of the critical social psychologist in elaborating on emerging forms of intimate subjectivities. Next, after detailing a small selection of Nikolas Rose's theorising on neoliberal intimate subjectivities, I put forward some suggestions about how sociological research could be bolstered by psychosocial theory. As Stephanie Taylor (2017) demonstrates, the field of psychosocial research is diverse, but is brought together through an interest in the connections between subjectivities and societies. While psychoanalytic traditions are typically drawn on, to follow, I make use of and explain the advantages of discursive and narrative traditions of psychosocial analysis (McAvoy, 2015; Scully, 2015; Taylor, 2015; Wetherell, 2008).

Whilst Rose's analysis, in common with other sociological texts (Giddens, 1992), makes links between individualisation and therapy discourses, his work stands out in its emphasis on the changes in subjectivity required to enable psy-societies (Rose, 1996, 1999), as well as other factors such as globalisation or technological changes (for example, Beck, 1992). Rose asserts that a therapeutic ethic has only been effective in instilling neoliberal aspirations of constant improvement through inspection and regulation of self, because people have reformed particular relations with the self (Rose, 1999). The knowledges of psy are diffuse, but our personal relationships are a primary site for exercising the choice and flexibility that is bound up in the neoliberal mandate, and confessions in the private sphere are understood as a key route to an authentic self (Rose, 1999).

While changes in neoliberal subjectivities have been approached through various critical social psychology fields, including health (Crawford, 2006; see Lyons \& Chamberlain, 2017, p.535; Riley, Evans, \& Robson, 2018) organisational psychology (McDonald, Wearing, \& Ponting, 2007), race theory (Salter \& Adams, 2013), gender (Evans, Riley, \& Shankar, 2010), and education (Bansel, Davies, Gannon, \& Linnell, 2008), to name just a few, a focus on intimacy is often omitted. Psychoanalytic concepts such as trauma and shame have been productively re-worked to explain how neoliberalism has taken a hold in contemporary western society (Layton, 2009, 2010), and to show the stubbornness of gender inequalities through women's internalisation of them (Seu, 2006). However, the ordinary quality of affective practices that reproduce neoliberal subjectivities, tends to get lost in such work (Wetherell, 2012, p.155). Another generative body of work showing the prevalence of neoliberal sensibilities can be found in studies of postfeminist cultures and psyches (Gill, 2017; Riley, Evans, Elliott, Rice, \& Marecek, 2017; Scharff, 2016). Yet, foci on intimacies and personal relationships in studies of postfeminism tend to be on various aspects of sexual relationships or disciplinary body practices, with the intersections with other types of (pluralising) intimacies remaining under-explored (for an exception see Kanai, 2016).

In contrast, and although not responding to Rose exclusively, a growing cohort of sociologists are producing nuanced, situated accounts of the influence of therapeutic and 


\section{DRAFT}

individualising neoliberal cultures in a range of relationship settings (Adkins, 2002; McLeod \& Wright, 2009; Swan, 2010; Wright, 2008). Similar to Lynn Jamieson's earlier, groundbreaking work examining 'disclosing intimacies' (1998), they emphasise the messiness, ambivalence and inconsistent use of technologies of psychologised selves. For example, Julie McLeod and Katie Wright interpret desires for disclosure as part of complex emotional strategies carried out by economically marginalised mothers and daughters (2009). Julie Brownlie demonstrates the incomplete nature of the psychologised knowledge of 'talking cures'; she finds that 'getting on with it' and not disclosing in personal relationships, is just as prevalent an aspirational ideal for many alongside mutual self-disclosure (2014). What then, might critical social psychologists add to these detailed, situated and thoughtful accounts?

While there is attention paid to biographical narratives and embodiment in some of these analyses, there is less detailing of the processes of identification and subjectification involved. Discursive and narrative psychosocial studies could provide the theoretical and methodological tools to extend analysis in this direction (Reynolds \& Taylor, 2005; Taylor, 2010; Taylor \& Littleton, 2006; Taylor \& McAvoy, 2014; Wetherell, 2008). Brownlie's (2014) account in particular shows common ground with psychosocial analysis. For example, in her use of the concept of 'practical consciousness' there is a wish to avoid treating knowledge and affect as oppositional (Brownlie, 2014, pp. 18-21; see Falmagne, 2016). Brownlie also centrally engages with a concern circulating in psychosocial studies (Taylor, 2017) - the problems of studying affect and emotion in the unspoken. As Stephanie Taylor points out however, suggestions that non-narrated aspects of 'interiority' go unacknowledged in discursive analysis have been challenged as relying on a narrow interpretation of discourse (Taylor, 2015). That is, discourse can capture the unsaid and non-textual affective practice if discourse is conceptualised as produced through all forms of meaning-making, including body actions and material contexts (Wetherell, 2013). In addition, the act of silencing or asking what is 'unsayable' can be a powerful tool in identifying affective practices, through discursive analysis.

Similar to my suggestions about how the family practices perspective in sociology could be extended, sociological work examining changes in emotional subjectivities could usefully include more developed theorising on the plural and distributed nature of identities (Bruner, 2001). It could also make use of available critical social psychology tools designed to put a spotlight on the management of multiple discursive positions, such as those found in poststructuralist, or repertoire-based (Wetherell, 1998) discursive psychology. Likewise, theories of narrative-discursive (Taylor, 2010) or personal order (Wetherell, 2007), investigating re-tellings of self, could be blended in. These shed light on how different versions of self become shaped by multiple histories, that layer, are performed through character, motives, intentions and beliefs, and are psychological and emotional in character (Wetherell, 2008). Future explorations of individualisation and therapeutic ways of being in personal relationships might begin by outlining patterns in identity practices - by tracking where the negotiation of imagined positions, the context-specific re-shaping of discursive resources and the dilemmas involved in intimate identities. In this way, people can be treated as inseparable from the (neoliberal) contexts in which they are produced, whilst recognising capacity for resistance, engendered through a discursive psychosocial approach and a focus on process and emergence (Taylor, 2015). 


\section{DRAFT}

\section{Discussion and conclusions}

My aim has been to promote discussion about existing nodes, intersections and divergences between critical social psychological projects related to personal life, and across into a sociology of personal life. It was not my goal to provide a comprehensive overview of existing work, or a prescriptive proposal for critical social psychological studies of personal life. Although, I have suggested that practice-based theories, including elements of a family practice approach, represent a useful model on which interdisciplinary studies of intimate practices might be loosely based. I cannot offer a tidy definition or a set of characteristics to define the practices or psychologised activities in the realm of personal life, and as Margaret Wetherell notes in relation to studying emotions as affective practices, this can feel unsatisfying (2012, p.97). Nevertheless, it is important that practices be defined through the common-sense ways that people construct such practices. Despite uncertainty and messiness, it is my hope that pockets of knowledge would form around different types of social practices, carried out by researchers with various similarities or differences in standpoints and disciplines, which intersect with other interests (e.g. education, health, gender, class, disability studies, relationship studies etc.). As well as making distinct critical social psychological impacts more visible within the increasingly interdisciplinary field of intimacy and personal life, conceiving intimate life as linking fields of practices would improve our abilities to track change or stasis between our local study sites, leveraging their significance.

Through three interrelated fields of practice and neighbourhoods of literature, I hope to have demonstrated why it is important that we put emphasis on the assumptions about the organisation of personal life, and their effects. Our identities as sexual beings and family members matter. But we must always keep in mind that they matter in a range of non-sexual, non-familial contexts; they need to be contextualised within the broader ideological sphere of intimate relating. In addition, increasingly, new forms of togetherness also require our attention. Keeping disciplinary boundaries porous can help us to be responsive to emerging intimate formations and subjectivities and to modes of relational selves.

As per my discussions on building a queered, interdisciplinary agenda for personal life, how we imagine our disciplinary boundaries and our academic communities can have significant effects in increasing inclusivity in various ways. I have focused my discussions on how blending discursive and/or practice theory into our psychosocial accounts of relational selves resolves some key debates that have emerged within sociology. Underpinning my suggestions, however, are more fundamental principles, central to both critical social psychological thinking and queer thinking - plurality, creativity, reconfiguring, blending, and the porosity of discourses or distinct ways of being. Dynamic intermixing should be a focus, even when examining regimes as omnipresent and pervasive as neoliberalism.

Of course, there may be times when we wish to emphasise elements of our work that are unrelated to matters of care, intimacy and the organisation of personal life, and others still when it is more appropriate to emphasise interdisciplinary differences rather than similarities. But given the important contributions critical social psychologists make to studies of intimacies and personal life, the overlaps with sociological work, and our emergence into a changed landscape of intimate relating and emotional formations, there is also good reason to cast a different eye on current disciplinary boundaries. 


\section{DRAFT}

\section{References}

Abeyasekera, A. L. (2017). "Living for others": Narrating agency in the context of failed marriages and singleness in urban Sri Lanka. Feminism \& Psychology, 27(4), 427-446. http://doi.org/10.1177/0959353517716951

Addie, E., \& Brownlow, C. (2014). Deficit and asset identity constructions of single women without children living in Australia: An analysis of discourse. Feminism \& Psychology, 24(4), 423-439. http://doi.org/10.1177/0959353514539463

Adkins, L. (2002). Revisions: Gender and sexuality in late modernity. Buckingham: Open University Press.

Allan, G., Crow, G., \& Hawker, S. (2011). Stepfamilies. London: Palgrave Macmillan.

Bansel, P., Davies, B., Gannon, S., \& Linnell, S. (2008). Technologies of audit at work on the writing subject: A discursive analysis. Studies in Higher Education, 33(6), 673-683. http://doi.org/10.1080/03075070802457017

Barker, M. (2005). This is my partner, and this is my partner's partner: Constructing a polyamorous identity in a monogamous world. Journal of Constructivist Psychology, 18(1), 75-78.

Bauman, Z. (1995). Forms of togetherness. In Life in Fragments (pp. 44-71). Oxford, Cambridge MA: Blackwell Publishers.

Bauman, Z. (2003). Liquid love. Cambridge: Polity Press.

Bauman, Z., \& May, T. (2001). Making it happen: Gifts, exchange and intimacy in relationships. In Thinking Sociologically (pp. 78-92). Oxford: Blackwell Publishing.

Beck, U. (1992). Risk society: Towards a new modernity. London: Sage.

Beck, U., \& Beck-Gernsheim, E. (1995). The normal chaos of love. Cambridge: Polity Press.

Beck, U., \& Beck-Gernsheim, E. (2002). Individualization: Institutionalized individualism and its social and political consequences. London: Sage. http://doi.org/10.1177/000169930204500212

Berlant, L. (2013). Intimacy: A special issue. Critical Inquiry, 24(2), 281-288.

Billig, M. (1996). Arguing and thinking: A rhetorical approach to social psychology (2nd ed.). Cambridge; New York: Cambridge University Press.

Billig, M. (2009). Discursive psychology, rhetoric and the issue of agency. Semen. Revue de Sémio-Linguistique Des Textes et Discours, 27. Retrieved from http://semen.revues.org/8930\#tocto1n4

Billig, M., Condor, S., Edwards, D., Gane, M., Middleton, D., \& Radley, A. (1988). Ideological dilemmas: A social psychology of everyday thinking. London: Sage.

Binkley, S. (2018). The emotional logic of neoliberalism: Reflexivity and instrumentality in three theoretical traditions in cultural dimensions. In D. Cahill, M. Cooper, M. Konings, \& D. Primrose (Eds.), The SAGE handbook of neoliberalism. London.

Bornstein, S. (2012). The law of gender stereotyping and the work-family conflicts of men. Hastings Law Journal, 63, 1297-1345.

Braun, V. (2003). Thanks to my mother ... A personal commentary on heterosexual marriage. Feminism and Psychology, 13(4), 421-425. 


\section{DRAFT}

http://doi.org/10.1177/09593535030134003

Braun, V., Clarke, V., \& Gray, D. (2017). Innovations in qualitative methods. In B. Gough (Ed.), The Palgrave handbook of critical social psychology (pp. 1-651). Basingstoke, New York, New York: Palgrave Macmillan. http://doi.org/10.1057/978-1-137-51018-1

Brown, S., \& Stenner, P. (2009). Psychology without foundations: History, philosophy and psychosocial theory. London: Sage Publications.

Brownlie, J. (2014). Ordinary relationships: A sociological study of emotions, reflexivity and culture. Basingstoke, New York: Palgrave Macmillan.

Bruner, J. (2001). Self-making and world-making. In B. Jens \& D. A. Carbaugh (Eds.), Narrative and identity: studies in autobiography, self and culture (pp. 25-37). Amsterdam, Philadelphia: John Benjamin Publishing Company.

Budgeon, S. (2006). Friendship and formations of sociality in late modernity: The challenge of 'post traditional intimacy. Sociological Research Online, 11(3). Retrieved from http://www.socresonline.org.uk/11/3/budgeon.html

Budgeon, S., \& Roseneil, S. (2002). Cultures of intimacy and care beyond "the family": friendship and sexual/love relationships in the twenty-first century. In International Sociological Association World Congress of Sociology, Brisbane July. Retrieved from http://www.leeds.ac.uk/cava/papers/culturesofintimacy.htm

Budgeon, S., \& Roseneil, S. (2004). Editors' introduction: Beyond the conventional family. Current Sociology, 52(2), 127-134. http://doi.org/10.1177/0011392104041797

Burns, A. (2000). Looking for love in intimate heterosexual relationships. Feminism and Psychology, 10(4), 481-485. http://doi.org/10.1177/0959353500010004008

Burns, A. (2003). The meanings of modern marriage. Feminism \& Psychology, 13(4), 511518. http://doi.org/10.1177/09593535030134015

Carter, J., \& Duncan, S. (2018). Reinventing couples: Tradition, agency and bricolage. London: Palgrave Macmillan.

Chambers, D. (2001). Representing the family. London: Sage Publications. http://doi.org/10.1017/CBO9781107415324.004

Chambers, D. (2012). A sociology of family life. Cambridge, UK: Polity Press.

Chambers, D. (2013). Social media and personal relationships: Online intimacies and networked friendship. Basingstoke, New York: Palgrave Macmillan.

Crawford, R. (2006). Health as a meaningful social practice. Health, 10(4), 401-420. http://doi.org/10.1177/1363459306067310

Daly, M. (2011). What adult worker model? A critical look at recent social policy reform in europe from a gender and family perspective. Social Politics, 18(1), 1-23. http://doi.org/10.1093/sp/jxr002

Duncan, S. (2011). Personal life, pragmatism and bricolage. Sociological Research Online, 16(4), 1-12. http://doi.org/10.5153/sro.2537

Edley, N. (2001). Analysing masculinity: Interpretative repertoires, ideological dilemmas and subject positions. In M. Wetherall, S. Taylor, \& S. J. Yates (Eds.), Discourse as data: a guide for analysis (pp. 189-228). Milton Keynes. 


\section{DRAFT}

Evans, A., Riley, S., \& Shankar, A. (2010). Technologies of sexiness: Theorizing women's engagement in the sexualization of culture. Feminism and Psychology, 20(1), 114-131. http://doi.org/10.1177/0959353509351854

Fagundes, C. P., \& Diamond, L. M. (2013). Intimate relationships. In Handbook of social psychology (pp. 371-411). http://doi.org/10.1007/978-94-007-6772-0

Falmagne, R. J. (2016). Toward the desegregation of thought and affect in psychological theorizing. Social and Personality Psychology Compass, 10(1), 3-10. http://doi.org/10.1111/spc3.12230

Farvid, P., \& Braun, V. (2017). Unpacking the "pleasures" and "pains" of heterosexual casual sex: Beyond Singular understandings. Journal of Sex Research, 54(1), 73-90. http://doi.org/10.1080/00224499.2016.1143442

Gabb, J. (2010). Researching intimacy in families. Palgrave Macmillan UK. http://doi.org/10.1057/9780230227668

Gergen, K. J. (2006). The relational self in historical context. International Journal for Dialogical Science, 1(1), 119-124.

Gibson, K., Wilson, J., Grice, J. Le, \& Seymour, F. (2017). Resisting the silence. Youth \& Society, 0044118X1772098. http://doi.org/10.1177/0044118X17720986

Giddens, A. (1991). Modernity and self-identity: self and society in the late modern age. Stanford: Stanford University Press.

Gill, R. (2017). The affective, cultural and psychic life of postfeminism: A postfeminist sensibility 10 years on. European Journal of Cultural Studies, 20(6), 606-626. http://doi.org/10.1177/1367549417733003

Griffin, C. (2000). Absences that matter: Constructions of sexuality in studies of young women's friendships. Feminism \& Psychology, 10(2), 227-245. http://doi.org/10.1177/0959353500010002003

Gross, N. (2005). The detraditionalization of intimacy reconsidered. Sociological Theory, 23(3).

Haritaworn, J., Lin, C. J., \& Klesse, C. (2006). Poly/logue: A critical introduction to polyamory. Sexualities, 9(5), 515-529. http://doi.org/10.1177/1363460706069963

Harre, R., \& Moghaddam, F. (2003). Introduction: The self and others in traditional psychology and in positioning theory. In R. Harre \& F. Moghaddam (Eds.), The self and others: Positioning individuals and groups in personal, political, and cultural contexts (pp. 1-11). Westport: Praeger.

Henderson, J., \& Forbat, L. (2002). Relationship-based social policy: Personal and policy constructions of "care." Critical Social Policy, 22(4), 669-687. http://doi.org/10.1177/02610183020220040601

Hepburn, A., \& Potter, J. (2011). Threats: power, family mealtimes and social influence. British Journal of Social Psychology, 50, 99-120. http://doi.org/10.1348/0144666 10X500791

Holdsworth, C., \& Morgan, D. (2005). Transitions in context: leaving home, independence and adulthood. Maidenhead: Open University Press.

Hussain, I., Johnson, S., \& Alam, Y. (2017). Young British Pakistani Muslim women's 


\section{DRAFT}

involvement in higher education. Feminism \& Psychology, 27(4), 408-426. http://doi.org/10.1177/0959353516686123

Jamieson, L. (1998). Intimacy: Personal relationships in modern societies. Cambridge, UK: Polity Press.

Jamieson, L. (1999). Intimacy transformed? A critical look at the 'pure relationship'. Sociology, 33(3), 477-494. http://doi.org/10.1177/S0038038599000310

Jeffreys, S. (2004). The need to abolish marriage. Feminism \& Psychology, 14(2), 327-331. http://doi.org/10.1177/0959353504040314

Johnson, K. (2012). Visualising mental health with an LGBT community group: Method, process, theory. Visual Methods in Psychology: Using and Interpreting Images in Qualitative Research, 173-189. http://doi.org/10.4324/9780203829134

Johnson, K. (2015). Sexuality: A psychosocial manifesto. Cambridge: Polity Press.

Kanai, A. (2016). Managing the self-social tension: Digital feminine self-production in an intimate public (PhD thesis).

Lahad, K. (2017). A table for one: A critical reading of singlehood, gender and time. Manchester: Manchester University Press.

Layton, L. (2009). Who's responsible? Our mutual implication in each other's suffering. Psychoanalytic Dialogues, 19(2), 105-120. http://doi.org/10.1080/10481880902779695

Layton, L. (2010). Irrational exuberance: Neoliberal subjectivity and the perversion of truth. Subjectivity, 3(3), 303-322. http://doi.org/10.1057/sub.2010.14

Lee, K. H. (2007). "Hello Lover": Commodification, Intimacy, and Second-Wave Feminism on Sex in the City. Hollywood, 6(2).

Levin, I. (2004). Best friends forever: Surviving a breakup with your best friend. Current Sociology, 52(2), 223-240. http://doi.org/10.1177/0011392104041809

Lyons, A. C., \& Chamberlain, K. (2017). Critical health psychology. In The Palgrave handbook of critical social psychology (pp. 533-555). http://doi.org/10.1057/978-1-13751018-1

Martinussen, M. (2018). Reason, season or life? Heterorelationality and the limits of intimacy between women friends. Forthcoming.

Martinussen, M., \& Wetherell, M. (2018a). Reading strategies for finding discursive subjectivities with feeling. Manuscript Submitted for Publication.

Martinussen, M., \& Wetherell, M. (2018b). "You won't believe what happened today": Women's friendship practices in psy-times. Manuscript Submitted for Publication.

Martinussen, M., Wetherell, M., \& Braun, V. (2018). Just being and being bad: Female friendship as a refuge in neoliberal times. Manuscript Submitted for Publication.

McAvoy, J. (2015). From ideology to feeling: Discourse, emotion, and an analytic synthesis. Qualitative Research in Psychology, 12(1), 22--33. http://doi.org/10.1080/14780887.2014.958357

McCarthy, J. R., Edward, R., \& Gillies, V. (2003). Making families : Moral tales of parenting and step-parenting. Durham, UK: Sociology Press.

McDonald, M., Wearing, S., \& Ponting, J. (2007). Narcissism and neo-liberalism: Work, and 


\section{DRAFT}

alienation in an era of consumption. Loisir et Societe, 30(2), 489-510.

http://doi.org/10.1080/07053436.2007.10707762

McKee, K. (2009). Post-foucauldian governmentality: What does it offer critcal social policy analysis. Critcal Social Policy, 29(3), 365-486.

McLeod, J., \& Wright, K. (2009). The talking cure in everyday life: Gender, generations and friendship. Sociology, 43(1), 122-139. http://doi.org/10.1177/0038038508099101

Meenagh, J. (2017). Breaking up and hooking up: A young woman's experience of "sexual empowerment." Feminism \& Psychology, 27(4), 447-464. http://doi.org/10.1177/0959353517731434

Meyers, S. A., \& Berscheid, E. (1997). The language of love: The difference a preposition makes. Personality and Social Psychology Bulletin, 23(4), 347-362. http://doi.org/10.1177/0146167297234002

Miettinen, R., Samra-Fredericks, D., \& Yanow, D. (2009). Re-turn to practice: An introductory essay. Organization Studies, 30(12), 1309-1327. http://doi.org/10.1177/0170840609349860

Molloy, E. (2008). Practice theory. In R. Thorpe \& E. Holt (Eds.), SAGE dictionary of qualitative management research (pp. 164-165). London: Sage Publications Ltd. http://doi.org/http://dx.doi.org.ezproxy.auckland.ac.nz/10.4135/9780857020109.n77

Morgan, D. (1989). Strategies and sociologists: A comment on crow. Sociology, 23(1), 2529.

Morgan, D. (1996). Family connections: an introduction to family studies. Cambridge, MA: Polity Press.

Morgan, D. (2011). Rethinking family practices. Basingstoke, New York: Palgrave Macmillan.

Morris, C. (2015). Considerations of equality in heterosexual single mothers' intimacy narratives. Sociological Research Online, 20(4), 1-11. http://doi.org/10.5153/sro.3817

Nardi, P. M. (1992). That's what friends are for: Friends as family in the gay and lesbian community. In K. Plummer (Ed.), Modern homosexualities: Fragments of lesbian and gay experience. Routledge.

Nash, C. (2005). Geographies of relatedness. Transactions of the Institute of British Geographers, 30(4), 449-462.

Oliveira, J. M. de, Costa, C. G. da, \& Carneiro, N. S. (2014). Troubling humanity: Towards a queer feminist critical psychology. Annual Review of Crticial Psychology, 11, 41-58.

Pahl, R., \& Spencer, L. (2004). Personal communities: Not simply families of 'fate' or 'choice. Current Sociology, 52(2), 199-221. http://doi.org/10.1177/0011392104041808

Park, S. M. (2013). Mothering queerly, queering motherhood resisting monomaternalism in adoptive, lesbian, blended, and polygamous families. Albany: NY: SUNY Press.

Peters, M. (2001). Poststructuralism, marxism, and neoliberalism: Between theory and politics. Lanham, MD: Rowman \& Littlefield Publishers.

Plummer, K. (2001). The square of intimate citizenship: Some preliminary proposals. Citizenship Studies, 5(3), 237-253. http://doi.org/10.1080/1362102012008522 


\section{DRAFT}

Reynolds, J., \& Taylor, S. (2005). Narrating singleness: Life stories and deficit identities. Narrative Inquiry, 15(2), 197-215. http://doi.org/10.1075/ni.15.2.02rey

Riley, S., Evans, A., Elliott, S., Rice, C., \& Marecek, J. (2017). A critical review of postfeminist sensibility. Social and Personality Psychology Compass, 11(12), 1-12. http://doi.org/10.1111/spc3.12367

Riley, S., Evans, A., \& Robson, M. (2018). Postfeminism and health: Critical psychology and media perspectives. London and New York: Routledge.

Rose, N. (1996). Inventing our selves: Psychology, power, and personhood. Cambridge Books Online. http://doi.org/http://dx.doi.org/10.1017/CBO9780511752179

Rose, N. (1999). Governing the soul: The shaping of the private self (2nd editio). London: Free Association Books.

Rosenbury, L. A., \& Rothman, J. E. (2010). Sex in and out of Intimacy. Emory Law Journal, 59, 809-868. Retrieved from

http://scholarship.law.ufl.edu/facultypub\%5Cnhttp://scholarship.law.ufl.edu/facultypub/ 720

Roseneil, S. (2000). Queer frameworks and queer tendencies: Towards an understanding of postmodern transformations of sexuality. Sociological Research Online, 5(3).

Roseneil, S. (2004). Why we should car e about friends: An argument forqueering the care imaginary in social policy. Social Policy and Society, 3(4), 409-419. http://doi.org/10.1017/S1474746404002039

Roseneil, S. (2006a). On not living with a partner: Unpicking coupledom and cohabitation. Sociological Research Online, 11(3), 1-14.

Roseneil, S. (2006b). The ambivalences of Angel's “arrangement”: A psychosocial lens on the contemporary condition of personal life. Sociological Review, 54(4), 847-869. http://doi.org/10.1111/j.1467-954X.2006.00674.x

Roseneil, S., \& Budgeon, S. (2004). Cultures of intimacy and care beyond 'the family': Personal life and social change in the early 21 st century. Current Sociology, 52(2), 135159. http://doi.org/10.1177/0011392104041798

Roseneil, S., \& Ketokivi, K. (2015). Relational persons and relational processes: Developing the notion of relationality for the sociology of personal life. Sociology, 50(1), 143-159. http://doi.org/10.1177/0038038514561295

Salter, P., \& Adams, G. (2013). Toward a critical race psychology. Social and Personality Psychology Compass, 7(11), 781-793. http://doi.org/10.1111/spc3.12068

Sandfield, A. (2006). Talking divorce: The role of divorce in women's constructions of relationship status. Feminism \& Psychology, 16(2), 155-173.

http://doi.org/10.1177/0959-353506062971

Sandfield, A., \& Percy, C. (2003). Accounting for single status: Heterosexism and ageism in heterosexual women's talk about marriage. Feminism \& Psychology, 13(4), 475-488.

Scharff, C. (2016). The psychic life of neoliberalism: Mapping the contours of entrepreneurial subjectivity. Theory, Culture \& Society, 33(6), 107-122. http://doi.org/10.1177/0263276415590164

Schatzki, T. R. (2001). Introduction: Practice theory. In T. R. Schatzki, K. K. Cetina, \& E. 


\section{DRAFT}

von Savigny (Eds.), The practice turn in comtemporary theory (pp. 1-14). London and New York: Routledge.

Scully, M. (2015). The problem of a subjective authenticity and the articulation of belonging among the Irish in England - a psychosocial approach. Qualitative Research in Psychology, 12(1), 34-44. http://doi.org/10.1080/14780887.2014.958369

Seu, B. I. (2006). Shameful selves: Women's feelings of inadequacy and constructed façades. European Journal of Psychotherapy \& Counselling, 8(3), 285-303. http://doi.org/10.1080/13642530600878196

Smart, C. (2007). Personal life: New directions in sociological thinking. Cambridge: Polity Press.

Stacey, J. (1996). In the name of the family. Boston: Beacon Press.

Stokoe, E. H. (2003). Mothers, single women and sluts: Gender, morality and membership categorization in neighbour disputes. Feminism \& Psychology, 13(3), 317-344. http://doi.org/10.1177/0959353503013003006

Swan, E. (2010). Worked up selves: Personal development workers, self-work and therapeutic cultures. Basingstoke, New York: Palgrave Macmillan.

Taylor, S. (2010). Narratives of identity and place. London: Routledge.

Taylor, S. (2015). Discursive and psychosocial? Theorising a complex contemporary subject. Qualitative Research in Psychology, 12(1), 37-41. http://doi.org/10.1080/14780887.2014.958340

Taylor, S. (2017). Psychosocial research. In B. Gough (Ed.), The Palgrave handbook of critical social psychology. Palgrave Macmillan.

Taylor, S., \& Littleton, K. (2006). Biographies in talk: A narrative-discursive research approach. Qualitative Sociology Review, 2(1), 22-38.

Taylor, S., \& McAvoy, J. (2014). Researching the psychosocial: An Introduction. Qualitative Research in Psychology, 12(1), 1-7. http://doi.org/10.1080/14780887.2014.958043

Triandafilidis, Z., Ussher, J. M., Perz, J., \& Huppatz, K. (2017). Doing and undoing femininities: An intersectional analysis of young women's smoking. Feminism \& Psychology, 27(4), 465-488. http://doi.org/10.1177/0959353517693030

Ussher, J. M., Perz, J., \& Parton, C. (2015). Sex and the menopausal woman: A critical review and analysis. Feminism and Psychology, 25(4), 449-468.

http://doi.org/10.1177/0959353515579735

Watts, S. (2017). Relationships: From social cognition to critical social. In B. Gough (Ed.), The Palgrave handbook of critical social psychology (pp. 365-385). Palgrave. http://doi.org/10.1057/978-1-137-51018-1

Weeks, J., Heaphy, B., \& Donovan, C. (2001). Same sex imtimacies: Families of choice and other life experiments. London: Routledge.

Weston, K. (1991). Families we choose: Lesbians, gays, kinship. New York: Columbia University Press.

Wetherell, M. (1998). Positioning and interpretative repertoires: conversation analysis and post-structuralism in dialogue. Discourse \& Society, 9(3), 387-412.

http://doi.org/10.1177/0957926598009003005 


\section{DRAFT}

Wetherell, M. (2003). Paranoia, ambivalence, and discursive practices: Concepts of position and positioning in psychoanalysis and discursive psychology. In R. Harre \& F. M. Moghaddam (Eds.), The self and others: Positioning individuals and groups in personal, political, and cultural contexts (pp. 99-120). Westport: Praeger.

Wetherell, M. (2005). Methods for studying intersectional and multiple identities: Troubled and untroubled subject positions and the macro/meso and micro. In ESRC Seminar Series, Methods in Dialogue. Cambridge, UK.

Wetherell, M. (2006). Formulating selves: Social psychology and the study of identity. Social Psychological Review, 8(2), 62-72.

Wetherell, M. (2007). A step too far: Discursive psychology, linguistic ethnography and questions of identity. Journal of Sociolinguistics, 11(5), 661-681. http://doi.org/10.1111/j.1467-9841.2007.00345.x

Wetherell, M. (2008). Subjectivity or psycho-discursive practices? Investigating complex intersectional identities. Subjectivity, 22(2008), 73-81. http://doi.org/10.1057/sub.2008.7

Wetherell, M. (2012). Affect and emotion: A new social science understanding. London: Sage Publications.

Wetherell, M. (2013). Affect and discourse - what's the problem? From affect as excess to affective/discursive practice. Subjectivity, 6(4), 349-368. http://doi.org/10.1057/sub.2013.13

Wetherell, M., \& Maybin, J. (1996). The distributed self: A social constructionist perspective. In R. Stevens (Ed.), Understanding the self (pp. 220-281). London.

Wright, K. (2008). Theorizing therapeutic culture: Past influences, future directions. Journal of Sociology, 44(4), 321-336. http://doi.org/10.1177/1440783308097124

Wright, M. W. (2010). Gender and geography II: Bridging the gap - feminist, queer, and the geographical imaginary. Progress in Human Geography, 34(1), 56-66.

http://doi.org/10.1177/0309132509105008

Zukas, M. (1993). Friendship as oral history: A feminist psychologist's view. Oral History, 21(2), 73-79. 